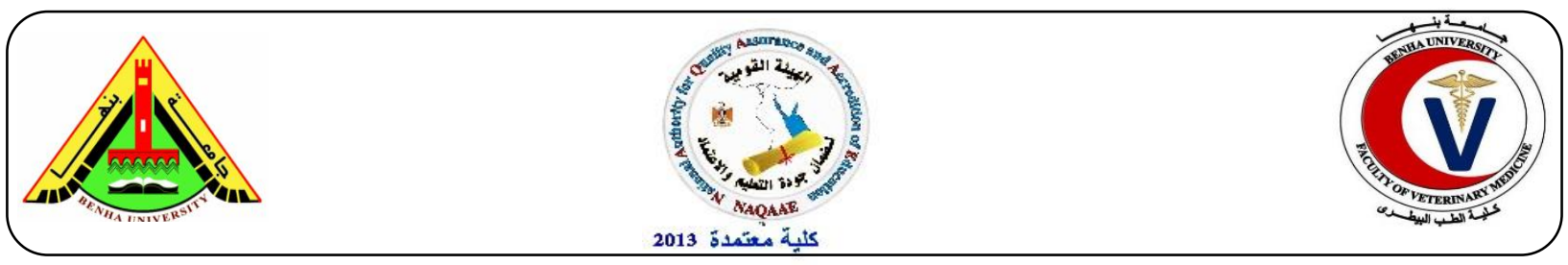

\title{
Detection and typing of Clostridium perfringens in some retail chicken meat products
}

\author{
Shaltout, F.A. ${ }^{1}$, Zakaria, I.M. ${ }^{2}$, Nabil, M.E. ${ }^{3}$ \\ ${ }^{1}$ Food hygiene Dept., Faculty of Veterinary Medicine, Benha University; ${ }^{2}$ Bacteriology Dept., Animal \\ Health Research Institute -Dokki; ${ }^{3}$ Food Control Dept.; Animal Health Research Institute (Benha Branch)
}

\section{A B S T R A C T}

Clostridium perfringens is considered as one of major food poisoning bacteria; which may refer to different lethal toxins production including $C$. perfringens enterotoxin. $C$. perfringens toxins have been contributed in many diseases in human being especially $C$. perfringens type A enterotoxin food poisoning. A total of 125 random raw and half cooked chicken meat samples represented by (breast, thigh, nuggets, panée and frankfurter "25 of each") were collected from various retail stores and supermarkets in Qualyubia governorate to investigate the presence of $C$. perfringens bacteriologically and detect the cpa, etx, and cpe toxin genes by multiplex PCR. Results demonstrated that 6 out of 25 raw breast samples (24\%), 8 out of 25 raw thigh samples (32\%), 5 out of 25 nuggets samples (20\%), 4 out of 25 panée samples (16\%), and 4 out of 25 frankfurter samples (16\%) were found to be contaminated with $C$. perfringens. Twenty-seven positive isolates obtained from these samples were identified as $C$. perfringens based on the microscopic examination and biochemical tests. It was detected that $8(29.6 \%)$ out of $27 C$. perfringens isolates carried only alpha toxin gene (type A), and only one isolate (3.7\%) of them expressed both alpha and epsilon toxin genes (type D); while cpe gene never had been detected in any examined isolate, according to the multiplex PCR results.

Keywords: chicken meat products, $C$. perfringens, multiplex PCR.

\section{INTRODUCTION}

Clostridium perfringens is a Gram-positive, spore-forming, anaerobic, non-motile bacilli that is commensally inhabit the intestine of animals and humans. It is frequently isolated from soil, skin, sewage and surface water. Animal and human feces are considered the natural source of contamination of food products. Because of its ability to produce spores under bad environmental conditions, it is one of the most widespread bacteria in nature as well as in the gastrointestinal tract of most animal species (Mokhtari and Doosti, 2015, Obrien and Melville, 2000).
Because of its commensal inhabitant of poultry intestinal tract, which contributed in feather, skin contamination followed by processing plant, defeathering machines, scalding tanks or pass from intestine during evisceration and contaminate carcass meat, so different stages of poultry processing line can add $C$. perfringens contamination source even starting from the hatchery (Voidarou $e t$ al., 2011).

Transmission of $C$. perfringens may occur via foodborne, water borne, animal contact, person-to-person, and others, at the point of consumption. $C$. perfringens transmission was referred primarily to food through unhygienic food handling and cross- 
contamination in the processing pathway (Butler et al., 2015). Because of its ability to form a spore, this microorganism is able to survive adverse conditions such as aerobic and food processing procedures. Its spores may contaminate meat and meat products either before processing and survive cooking or after processing due to unhygienic handling of prepared food (Santos et al., 2002 and Potter, 2001).

The virulence factor of $C$. perfringens strains is associated with several toxins production, within them, all strains produce alpha $(\alpha)$ toxin encoded by cpa gene; other major lethal toxins are beta $(\beta)$, epsilon $(\varepsilon)$ and iota $(l)$. In addition to these major lethal toxins, some strains, with a ratio of 0 to $5 \%$, have a capability of producing $C$. perfringens enterotoxin encoded by cpe gene that is the main cause of common $C$. perfringens type A food poisoning (McClane, 2007 and Juneja et al., 2010).

All type A strains produce $\alpha$ toxin, type $\mathrm{B}$ produce $\alpha, \beta$ and $\varepsilon$ toxins, type $\mathrm{C}$ produce $\alpha$ and $\beta$ toxins, type D produce $\alpha$ and $\varepsilon$ toxins, while type E produce $\alpha$ and 1 toxins. $C$. perfringens types (B-E) are recognized as "frank pathogens" for animals and human, while type A strains are commensally inhabit the GIT of them. $C$. perfringens type A strains are implicated in numerous human diseases such as foodpoisoning and gastrointestinal illness (Fisher et al., 2005).

Alpha toxin is a necrotizing toxin produced by all $C$. perfringens strains; the purified toxin can cause serious acute pulmonary disease, as well as vascular leak, hemolysis, thrombocytopenia and liver damage. Epsilon (etx) toxin is one of twelve proteinaceus toxins produced by $C$. perfringens (types $\mathrm{B}$ and $\mathrm{D}$ ); this toxin is a pore-forming protein; in addition to production of alpha toxin. Beta toxin is a lethal necrotizing toxin found in types B and
C. Theta toxin is an oxygen-labile cytolysin; this toxin can damage blood vessels, resulting in leukostasis, thrombosis, decreased perfusion and tissue hypoxia; Theta toxin also stimulates cytokine release and can cause shock (The center for food security and public health, 2004).

C. perfringens type A foodborne illness occur after the ingestion of food contaminated with a large number $\left(10^{6}-10^{8}\right.$ cells/g) of type A viable vegetative $C$. perfringens cells specially meat and meat products. After ingestion, $C$. perfringens enterotoxin (cpe) has been produced during inter-intestinal sporulation (McClane and Rood, 2001).

C. perfringens type A is contributed in much human foodborne gastroenteritis, such as food poisoning, sporadic diarrhea, antibiotic-associated diarrhea, and nosocomial diarrhea outbreaks. $C$. perfringens was estimated to cause $10 \%$ (1 million cases) of recorded USA food poisoning cases/year. Deaths from $C$. perfringens type $\mathrm{A}$ food poisoning are not common but may occur in the elderly and debilitated patients. C. perfringens type A food poisoning is contributed to kill seven people in the USA and between 100 people in the UK (Byrne et al., 2008 and Scallan et al., 2011).

C. perfringens enterotoxin is thought to be the main causative agent of $C$. perfringens food-borne gastroenteritis. Recently, some outbreaks of food poisoning, non-CPE producers of $C$. perfringens were isolated. These results suggest that enterotoxin of $C$. perfringens can be causative agents of acute gastroenteritis in humans (Yongi et al., 2014).

C. perfringens type A food poisoning is characterized by symptoms of diarrhea and abdominal cramps with rare signs of fever or vomition; the course of disease can 
be peracute, acute, or chronic, with signs of the acute and peracute condition including intense abdominal pain, depression, and bloody diarrhea (Shimizu et al., 2002 and Rahimi et al., 2011).

Classical typing of $C$. perfringens has been performed by toxin neutralization with mice or guinea pigs; because these methods are time consuming and expensive, they have largely been replaced by PCR-based detection methods. In recent years, various PCR protocols, including multiplex PCR assays, have been established to toxin-typing of $C$. perfringens isolates with respect to the genes $c p a, c p b$, etx, iA, cpe and $c p b 2$, encoding the alpha, beta, epsilon, iota, entero- and b2-toxin, respectively (Al-Khaldi et al. 2004; Baums et al., 2004).

C. perfringens strains that associated with food poisoning outbreaks are carrying their enterotoxin gene, cpe, on their chromosome, while $C$. perfringens strains isolated from non-foodborne cases, such as antibiotic-associated diarrhea (AAD) and sporadic diarrhea, carry cpe on the plasmid. Investigation of 31 clinical and non-clinical $C$. perfringens isolates to locate the cpe gene by PCR is performed; where cpe of nine heat-sensitive strains isolated from three outbreaks of food poisoning were located on the plasmid, while those of heat-resistant strains from other food poisoning outbreaks were located on the chromosome. Moreover, the cpe of 5 heat-sensitive strains isolated from healthy human feces were located on the plasmid. They concluded that heatsensitive, cpe-plasmid-borne $C$. perfringens strains should not be disregarded as causative agents of food poisoning (Nakamura et al., 2004).

Therefore, this study aimed to detect and typing of $C$. perfringens in some chicken meat products by biochemical and multiplex PCR methods.

\section{MATERIAL AND METHODS}

\subsection{Collection of samples:}

A total of 125 random samples of fresh raw and partially cooked chicken meat products represented by (breast, thigh, nuggets, panée and frankfurter (25 of each), respectively; were collected from different retail groceries and supermarkets in Qalyubiya governorate for bacteriological and molecular examination. All the collected samples were subjected to the following examination.

\subsection{Preparation of the samples:}

It was done according to (APHA, 1992).

\subsection{Detection of $C$. perfringens:}

It was done according to (ISO, 2004) using TSC media.

\subsection{Isolation of C. perfringens:}

It was done according to (Carter and Cole, 1990) using cooked meat media and $10 \%$ sheep blood agar.

\subsection{Identification of $C$. perfringens:}

It was done according to (MacFaddine, 1980 and Cato et al., 1986).

\subsubsection{Staining:}

It was done according to (Cruickshank et al., 1975).

\subsubsection{Cultural characteristics:}

It was done according to (Cruickshank et al., 1975):

2.5.2.1. Cooked meat media (BioMed).

2.5.2.2. Sheep blood agar media.

2.5.2.3.Egg yolk agar media (Nagler's reaction).

\subsubsection{Nutrient gelatin media.}

\subsubsection{Biochemical reactions}

2.5.2.6. Nitrate reduction test was done according to (Willis, 1977) 
Detection and typing of Clostridium perfringens in some retail chicken meat products

2.5.2.7.Zinc Test was done according to (Willis, 1977)

2.5.2.8. Indole production test it was done according to (MacFaddine, 1980)

2.5.2.9. Hydrogen sulphid test it was done according to (MacFaddine, 1980)

2.5.2.10. Sugar fermentation test it was done according to (Willis, 1977)

\begin{tabular}{llrr} 
2.5.3. Detection & \multicolumn{2}{r}{ of } & \multicolumn{2}{r}{ Clostridium } \\
perfringens & toxins & by & using \\
Multiplex & PCR & was & done \\
according to & Kalender & et al. \\
(2005), Moller and Ahrens & (1996), \\
and Meer and Songer(1997). &
\end{tabular}

\section{RESULTS}

As illustrated in table (2) and Pic. (1): Out of 125 raw and half processed chicken meat products, 27(21.6\%) samples were found to be contaminated with $\mathrm{C}$. perfringens in incidence of 24, 32, 20, 16 and $16 \%$ from examined raw breast, raw thigh, nuggets, panée and frankfurter samples, respectively. eight $(29.6 \%)$ isolates were confirmed as $\mathrm{C}$. perfringens type $\mathrm{A}$ after detection of alpha toxin gene that gave a characteristic ampilicon band at 402bp; and only one isolate $(3.7 \%)$ gave the characteristic fragment of epsilon toxin encoded by etx at base pairs 541 indicated C. perfringens type D using multiplex PCR; In addition, it was determined that none of the isolates carried $\mathrm{C}$. perfringens enterotoxin (cpe) genes.

Table (1): Primer sequences of $C$. perfringens enterotoxin genes used for Multiplex PCR identification system:

\begin{tabular}{|c|c|c|c|c|}
\hline $\begin{array}{l}\text { Target } \\
\text { toxin gene }\end{array}$ & Primer & $\begin{array}{l}\text { Oligonucleotide sequence } \\
\qquad\left(5^{\prime} \rightarrow 3^{\prime}\right)\end{array}$ & $\begin{array}{l}\text { Amplicon } \\
\text { length (bp) }\end{array}$ & Reference \\
\hline \multirow{2}{*}{ A } & cpa $(\mathrm{F})$ & 3' AAG ATT TGT AAG GCG CTT '5 & \multirow{2}{*}{402} & \multirow{2}{*}{$\begin{array}{l}\text { Kalender et al. } \\
\text { (2005) }\end{array}$} \\
\hline & cpa $(\mathrm{R})$ & $3^{\prime}$ ATT TCC TGA AAT CCA CTC '5 & & \\
\hline \multirow{4}{*}{$\begin{array}{c}\text { D } \\
\text { enterotoxin }\end{array}$} & $\operatorname{etx}(\mathrm{F})$ & 3'GCGGTGATATCCATCTATTC '5 & \multirow{2}{*}{541} & Moller and \\
\hline & $\operatorname{etx}(\mathrm{R})$ & 3'CCACTTACTTGTCCTACTAAC '5 & & Ahrens (1996) \\
\hline & cpe $(\mathrm{F})$ & 3'GGAGATGGTTGGATATTAGG'5 & \multirow{2}{*}{233} & Meer and Songer \\
\hline & cpe (R) & 3'GGACCAGCAGTTGTAGATA'5 & & (1997) \\
\hline
\end{tabular}


Table (2): incidence and typing of $C$. perfringens in the examined chicken meat product samples $(\mathrm{n}=25)$.

\begin{tabular}{|c|c|c|c|c|c|c|c|c|}
\hline \multirow{3}{*}{ Samples } & \multicolumn{2}{|c|}{ Positive samples } & \multicolumn{6}{|c|}{ Types of isolates } \\
\hline & \multirow{2}{*}{ No. } & \multirow{2}{*}{$\%$} & \multicolumn{2}{|c|}{$\mathrm{A}(c p a)$} & \multicolumn{2}{|c|}{$\mathrm{D}(e t x)$} & \multicolumn{2}{|c|}{ cpe } \\
\hline & & & No. & $\%$ & No. & $\%$ & No. & $\%$ \\
\hline \multicolumn{9}{|c|}{ Raw chicken meat } \\
\hline Chicken breast & 6 & 24 & 2 & 33.3 & 0 & 0 & 0 & 0 \\
\hline Chicken thigh & 8 & 32 & 2 & 25 & 1 & 12.5 & 0 & 0 \\
\hline \multicolumn{9}{|c|}{ Half cooked chicken meat products } \\
\hline Chicken nuggets & 5 & 20 & 1 & 20 & 0 & 0 & 0 & 0 \\
\hline Chicken panée & 4 & 16 & 2 & 50 & 0 & 0 & 0 & 0 \\
\hline Chicken frankfurter & 4 & 16 & 1 & 25 & 0 & 0 & 0 & 0 \\
\hline Total & 27 & 21.6 & 8 & $29.6^{*}$ & 1 & $3.7^{*}$ & 0 & 0 \\
\hline
\end{tabular}

*- in relation to total number of isolates (27).

Pic. (1): Agarose gel electrophoresis of multiplex PCR for detection of C. perfringens (type $\mathrm{A}, \mathrm{D}$ and enterotoxin) toxin genes.

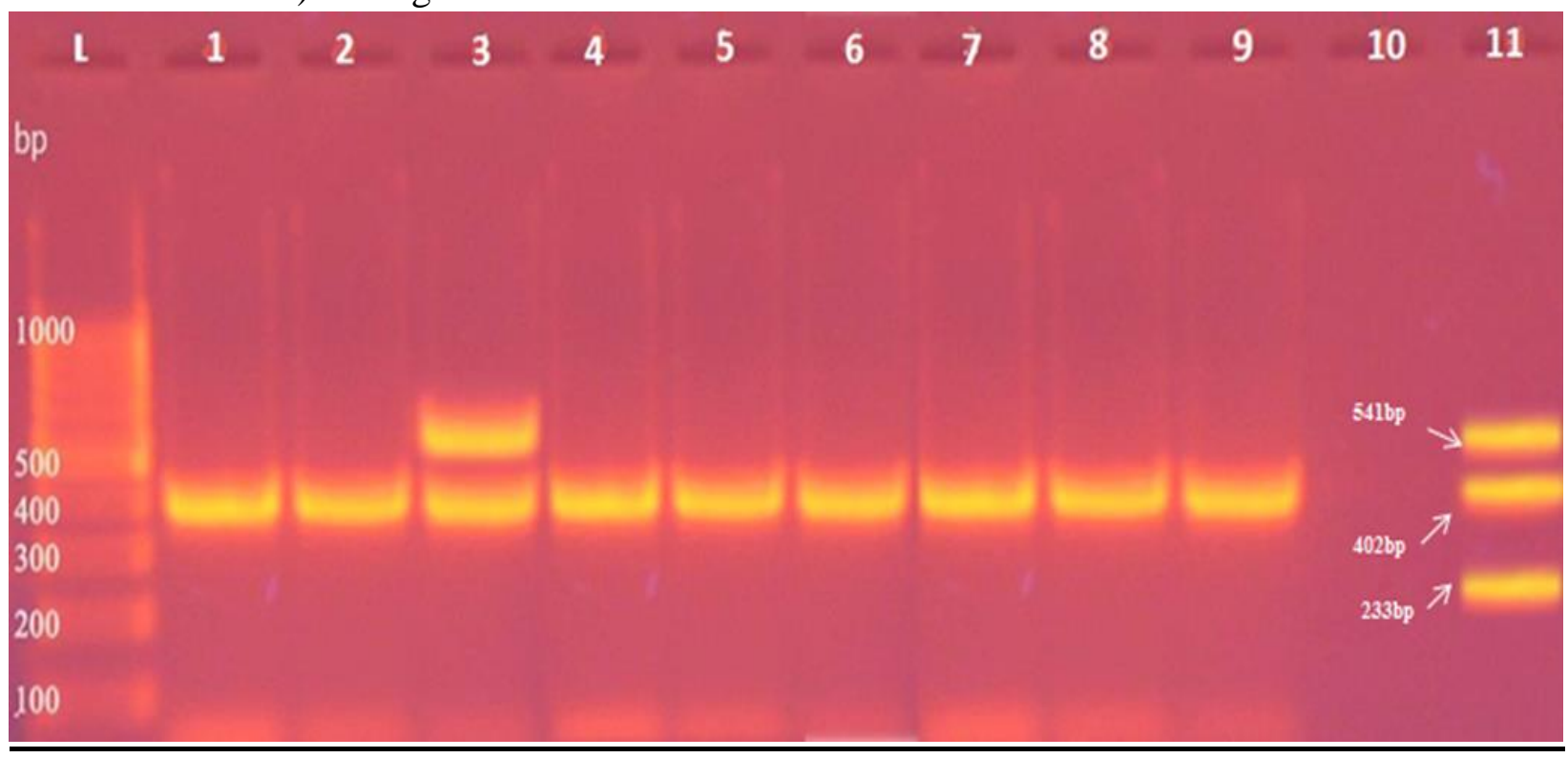

Lane L: 100 bp ladder as molecular DNA size marker.

Lane 1: Control positive for cpa (402bp), etx (541bp) genes, and cpe (233bp).

Lane 11: Control negative.

Lanes 2, 3, 5, 6, 7, 8, 9 and 10: Positive samples for alpha toxin (cpa-type A).

Lanes 4: Positive samples for epsilon toxin (etx- type D).

Lane 11: negative control sample. 


\section{DISCUSSION}

Foods of animal origin such as poultry meat, which are high in protein, have great importance in the occurrence of food poisoning depending on $C$. perfringens; factors are widely available in the products of raw meat and half cooked meats prepared with these contaminated meats.

Results tabulated in table (2) are in agree with (Zakaria, 2005) who recorded isolation of $C$. perfringens in examined chicken breast, thigh and frankfurter samples in prevalence of 25, 35, 10\%; (Emara, 2014) who detected C. perfringens in $30 \%$ of examined fillet samples; (Nabil et al., 2014) who detected $C$. perfringens in $13.3 \%$ of examined frankfurter samples; (Sobhy, 2016) who detected C. perfringens in $36.6 \%$ of examined raw samples.

Adversely, results were lower than that reported by (Prabhu et al., 2013) who detected C. perfringens in $81.69 \%$ of examined samples; (Torky and Hassan, 2014) who detected C. perfringens in $70 \%$ of examined chicken meat samples; while, higher than those reported by (Thangamani and Subramanian, 2012) who detected $C$. perfringens in $3.81 \%$ of examined samples; (Afshari et al., 2015) who detected $C$. perfringens in $15.5 \%$ of examined chicken meat samples. Moreover, reported results were disagreed with (Hashem, 2015) and (Ibrahim-Hemmat et al., 2015) who failed to detect $C$. perfringens in any examined chicken meat sample; and (Nasr et al., 2007) who did not detect $C$. perfringens in any examined nuggets samples.

Differences may be attributed to difference in circumstances of hygienic measures effectiveness during slaughtering, processing practices, handling from production to consumption. In case of chicken products, differences can be attributed to the difference in bacterial load of used raw materials; addition of additives, spices and preservatives as well as the conditions occurred before and after slaughtering of the birds affects the bacterial load in these products.

It is not wearing that, all examined $C$. perfringens isolates were found to be positive according to multiplex PCR results, where $29.6 \%$ of them were determined as type A. It can be explained by: (1) the fact that cpa toxin gene are commonly present gene in all $C$. perfringens types, (2) $C$. perfringens type $\mathrm{A}$ is dominant in almost all of the research concerning poultry meat as reported by (Lin and Labbe 2003; Nowell et al. 2010).

According to multiplex PCR results as showing in table (2) and pic.1, out of examined $C$. perfringens isolates, $29.6 \%$ of isolates were confirmed as $C$. perfringens type A (cpa), and $3.7 \%$ isolate was $C$. perfringens type $\mathrm{D}$ (etx); while failed to detect enterotoxin production gene (сpe); which were in agree with (Erol et al., 2008) who reported that recent studies claimed that C. perfringens type A foodborne poisonings are rarely associated with enterotoxin encoding by the cpe gene it is only detected in $(0-5 \%)$ of outbreaks isolates.

So, our results are logically in agree with (Abd Al-Tawab et al., 2015) (Prabhu et al., 2013), (Salah El-din et al., 2015) who proved that all their PCR examined $C$. perfringens isolates gave a characteristic band at 402bp (cpa only); Torky and Hassan (2014) revealed $66 \%$ of multiplex PCR examined isolates gave bands at $402 \mathrm{bp}$ and $33.3 \%$ gave both bands at 402 and $541 \mathrm{bp}$, which referring to $C$. perfringens type A (сpa) and $C$. perfringens type $\mathrm{D}$ (etx), respectively; while failed to detect either $C$. perfringens type $\mathrm{B}$ or $\mathrm{C}$. While it disagreed with (Afshari et al., 2015) who detected type A $(29.03 \%)$, type C $(70.96 \%)$, and cpe 
(25.00\%) toxin genes in examined $C$. perfringens isolates.

These findings proved that presence of $C$. perfringens bacteria in either raw or half cooked chicken meat products in a great number may be responsible for inferior quality of meat products resulting in economic losses and the possibility of causing public health hazard. Meat and meat products can be contaminated with $C$. perfringens especially of type A through many sources which contributing a significant public heath threating factor. Recommendations include following a strict hygienic measure throughout the whole meat and meat products manufacturing starting from slaughtering to consumption to minimize bacterial contamination and safeguard human health.

\section{REFERENCES}

Abd Al-Tawab, A.A.; El-Hofy-Fatma, I.; Khater-Dalia, F.; Kotb, M.M. 2015. "Typing of Clostridium perfringens isolated from some meat products by using PCR". Benha Vet. Med. J., 29(1):118-123.

Afshari, A.; Jamshidi, A.; Razmyar, J.; Rad, M. 2015. "Genotyping of Clostridium perfringens isolated from broiler meat in northeastern of Iran". Veterinary Research Forum, 6(4): 279-284.

Al-Khaldi, S.F.; Myers, K.M.; Rasooly, A.; Chizhikov, V. 2004. "Genotyping of Clostridium perfringens toxins using multiple oligonucleotide microarray hybridization". Mol. Cell Probes, 18: 359-367.

American Public Health Association "APHA" 1992. "Compendium of methods for the microbiological examination of foods. $3^{\text {rd }}$ Ed. APHA Technical Committee on Microbiological Methods for Foods. Washington, D. C. USA.
Baums, C.G.; Ulrich, S.; Gunter, A.; Goethe, R. 2004. "Diagnostic Multiplex PCR for toxin genotyping of C. perfringens isolates". Vet. Microbiol., P. 11-16.

Butler, A.J.; Thomas, M.K.; Pintar, K.D. 2015. "Expert elicitation as a means to attribute 28 enteric pathogens to foodborne, waterborne, animal contact, and person-to-person transmission routes in Canada". Food borne Pathog. Dis., 12(4): 335-344.

Byrne, B.; Scannell, A.G.M.; Lyng, J.; Bolton, D.J. 2008. "An evaluation of Clostridium perfringens media". Food Control, 19: 1091-1095.

Carter, G.R.; Cole, J.R. 1990. "Diagnostic procedures in veterinary bacteriology and mycology". 5 ${ }^{\text {th }}$ Ed., Academic Press, Harcourt, Boace. J., New York, Boston, Tokyo, Toronto.

Cato, E.P.; George, W.L.; Finegold, S.M. 1986. "Bergeys manual of systematic bacteriology, Vol.2. Williams and Wilkins, Baltimore, USA.

Cruickshank, R.; Duguid, J.P.; Marmion, B.P.; Swain, R.H. 1975. "Medical Microbiology". $2^{\text {nd }}$ Ed., Vol.2. The Practice of Medical microbiology, Churchill Living Stone Edinburgh.

Emara, M.S. 2014. "Anaerobic and aerobic microorganisms in human food". M. V. Sc. Thesis, Fac. Vet. Med., Cairo Univ., Egypt.

Erol, I.; Göncüoğlu, M.; Ayaz, N. D.; Bilir Ormanci, F.S.; Hildebrandt, G. 2008. "Molecular typing of Clostridium perfringens isolated from turkey meat by multiplex PCR". Lett. Appl. Microbiol., 47: 31-34.

Fisher, D.J.; Miyamoto, K.; Harrison, B.; Akimoto, S.; Sarker, M.R.; McClane, B.A. 2005. "Association of $\beta 2$ toxin production with Clostridium perfringens type A human gastrointestinal disease isolates carrying a plasmid enterotoxin gene". Mol. Microbiol., 56: 747-762. 
Detection and typing of Clostridium perfringens in some retail chicken meat products

Hashem, H.M. 2015. "Bacteriological criteria of dressed poultry with special reference to some microbial decontaminators". M. V. Sc. Thesis, Fac. Vet. Med., Benha Univ., Egypt.

Ibrahim-Hemmat, M.; Amin-Reham, A.; ElShater, M.A.; Hafez-Salwa, M. 2015. "Bacteriological evaluation of freshly slaughtered chicken carcasses". Benha Vet. Med. J., 28(2): 74-82.

International Standard Organization "ISO" 2004. "Microbiology of food and animal feeding stuffs-horizantal method for the enumeration of Clostridium perfringens-colony count technique". Ref. No. ISO 7937:2004.

Juneja, V.K.; Novak, J.S.; Labbe, R.L. 2010. "Clostridium perfringens". In: Pathogens and Toxins in Foods: Challenges and Interventions. Juneja, V. K., Sofos, J. N. (Eds.)., ASM Press, Washington D.C., P. 53-70.

Kalender, H., Ertas, H.; Cetinkaya, B.; Muz, A.; arslan, N.; Kilic, A. 2005. "Typing of isolates of $C$. perfringens from healthy and diseased sheep by multiplex PCR". Vet. Med. Czech, 50 (10): 439-442.

Lin, Y.T.; Labbe, R. 2003. "Enterotoxigenicity and genetic relatedness of Clostridium perfringens isolates from retail foods in the United States". Appl. Environ. Microbiol., 69: 1642-1646.

MacFaddine, F. 1980. "Biochemical tests for identification of medical bacteria". $2^{\text {nd }}$ Ed., Williams and Wilkins, Baltimore, USA.

McClane, B.A. 2007. "Clostridium perfringens". In: Food Microbiology, Fundementals and Frontiers. Doyle, M. P., Beuchat, L. R. (Eds.), $3^{\text {rd }}$ ed., ASM Press, Washington D.C., P. 423-444.

McClane, B.A.; Rood, J.I. 2001. "Clostridial toxins involved in human enteric and histotoxic infection". In: Clostridia:
Biotechnology and Medical Applications. Bahl H, Dürre $\mathrm{P}$. (Eds.), Wiley-VHC Weinheim, p. 169-220.

Meer, R.R.; Songer, J.G. 1997. "Multiplex polymerase chain reaction assay for genotyping Clostridium perfringens". Amer. J. Vet. Res., 58: 702-705.

Mokhtari, F.A.; Doosti, A. 2015. "Investigation of antibiotic resistance and frequency of Clostridium difficile $t c d A$ and $t c d B$ genes in feces of calves in Chaharmahal Va Bakhtiari province". Journal of Shahrekord University of Medical Sciences, 17: 35-42.

Moller, K.; Ahrens, P. 1996. Comparison of toxicity neutralization; ELISA- and PCR tests for typing of Clostridium perfringens and detection of the enterotoxin gene by PCR. Anaerobe 2103-110.

Nabil, M.E.; Edris, A.M.; Shaltout, F.A.; Zakaria, I.M. 2014. "Effect of some preservatives on bacterial load of some poultry meat products". Benha Vet. Med. J., 26(1): 94-103.

Nakamura, M.; Kato, A.; Tanaka, D.; Gyobu, Y.; Higaki, S.; Karasawa, T.; Yamagishi, T. 2004. "PCR identification of the plasmid-borne enterotoxin gene (cpe) in Clostridium perfringens strains isolated from food poisoning outbreaks". International Journal of Medical Microbiology, 294(4): 261-265.

Nasr, E.M.; Shehta, A.A.; Amer, H.A. 2007. "Enterotoxigenicity and typing of Clostridium perfringens isolates from some poultry products in Egypt". J. Appl. Sci. Res., 3(12): 1804-1808.

Nowell, V.J.; Parreira, V.R.; Jiang, Y.F.; Reid-Smith, R.; Prescott, J.F. 2010. "Clostridium perfringens in retail chicken”. Anaerobe, 16(3):314-315.

Obrien, D.K.; Melville, S.B. 2000. "The anaerobic pathogen Clostridium 
perfringens can escape the phagosome of macrophages under aerobic conditions". Cellular Microbiol., 2: 505-519.

Potter, N. 2001. "Food sciences". $3^{\text {rd }}$ Ed., AVI Publishing Co. Inc., NY, USA.

Prabhu, N.K.; Ruban, W.S.; Naveen, B.R.; Raghunath, B. V. 2013. "Molecular characterization of alpha toxin gene of Clostridium perfringens from chicken meat". J. Cell and Tissue Res., 13(1): 3455-3458.

Rahimi, S.; Kathariou, S.; Grimes, J.L.; Siletzky, R.M. 2011. "Effect of direct-fed microbials on performance and Clostridium perfringens colonization of turkey poults". Poultry Science, 90: 2656-2662.

Salah-Eldin, A.H.; Fawzy, E.H.; Aboelmagd, B.A.; Ragab, E.A.; Bedawy, S. 2015. "Clinical and laboratory studies on chicken isolates of Clostridium Perfringens in ElBehera, Egypt". J. World's Poult. Res., 5(2): 21-28.

Santos, G.; Mirna, A.; Marivael, G.; Nerma, H. 2002. "Inhibition of growth enterotoxin production, and spore formation of $C$. perfringens by extracts of medicine plants". J. Food Protect., 65(10): 1667-1669.

Scallan, E.; Hoekstra, R.M.; Angulo, F.J.; Tauxe, R.V.; Widdowson, M.A.; Roy, S.L.; Jones, J.L.; Griffin, P.M. 2011. "Foodborne illness acquired in the United States- major pathogens". Emerg. Infect. Dis., 17: 7-15.

Shimizu, T.; Ohtani, K.; Hirakawa, H.; Ohshima, K.; Yamashita, A.; Shiba, T.; Ogasa-wara, N.; Hattori, M.; Kuhara, S. and Hayashi, H. (2002): "Complete genome sequence of Clostridium perfringens, an anaerobic flesh-eater". Proceedings of the National Academy of Sciences, 99: 996-1001.

Sobhy, A. E. (2016): "Microbial status of meat and chicken received to university hostel". M. V. Sc. Thesis, Fac. Vet. Med., Benha Univ., Egypt.

Thangamani, A. and Subramanian, S. (2012): "Prevalence of Clostridium perfringens in the chicken meat rendered at retail outlets of Namakkal, Tamilnadu". Journal of Advanced Veterinary Research, 2: 157-159.

The center for food security and public health (2004): "Epsilon Toxin of Clostridium perfringens". Institute for international cooperation in animal biologics, Fac. Vet. Med., Iowa Univ., USA., p. 1-4.

Torky, H.A.; Hassan, M.A. 2014. "Sequence analysis of alpha toxin produced by $C$. perfringens isolated from different sources". Nature and Science, 12(1): 55-61.

Voidarou, C.; Vassos, D.; Rozos, G.; Alexopoulos, A.; Plessas, A.; Tsinas, A.; Skoufou, M.; Stavropoulou, E.; Bezirtzoglou, E. 2011. "Microbial challenges of poultry meat production". Anaerobe, 17: 341-343.

Willis, A.T. 1977. "Anaerobic Bacteriology Practice". $\quad 3^{\text {rd }} \mathrm{Ed}$. Butter Worths, London.

Yongi, S.; Matsuda, S.; Kawai, T.; Yoda, T.; Harada, T.; Kumeda, Y.; Gotoh, K.; Hiyoshi, H.; Nakamur, M.; Kodama, T.; Lida, T. 2014. "BEC, a novel enterotoxin of $C$. perfringens found in human clinical isolates from acute gastroenteritis outbreaks". Infect. Immunol., 82(6): 2390-2399.

Zakaria, I.M. 2005. "Anaerobic bacteria in chicken meat products". M. V. Sc. Thesis, Fac. Vet. Med., Zagazig University, Benha branch. 